Article

\title{
Flux-Reducing Tendency of Pd-Based Membranes Employed in Butane Dehydrogenation Processes
}

\author{
Thijs A. Peters * ${ }^{*}$, Marit Stange and Rune Bredesen \\ SINTEF Industry, P.O. Box 124 Blindern, N-0314 Oslo, Norway; marit.stange@sintef.no (M.S.); \\ rune.bredesen@sintef.no (R.B.) \\ * Correspondence: thijs.peters@sintef.no; Tel.: +47-982-439-41
}

Received: 29 September 2020; Accepted: 14 October 2020; Published: 16 October 2020

check for updates

\begin{abstract}
We report on the effect of butane and butylene on hydrogen permeation through thin state-of-the-art Pd-Ag alloy membranes. A wide range of operating conditions, such as temperature (200-450 ${ }^{\circ} \mathrm{C}$ ) and $\mathrm{H}_{2} /$ butylene (or butane) ratio (0.5-3), on the flux-reducing tendency were investigated. In addition, the behavior of membrane performance during prolonged exposure to butylene was evaluated. In the presence of butane, the flux-reducing tendency was found to be limited up to the maximum temperature investigated, $450{ }^{\circ} \mathrm{C}$. Compared to butane, the flux-reducing tendency in the presence of butylene was severe. At $400{ }^{\circ} \mathrm{C}$ and $20 \%$ butylene, the flux decreases by $\sim 85 \%$ after $3 \mathrm{~h}$ of exposure but depends on temperature and the $\mathrm{H}_{2}$ /butylene ratio. In terms of operating temperature, an optimal performance was found at $250-300{ }^{\circ} \mathrm{C}$ with respect to obtaining the highest absolute hydrogen flux in the presence of butylene. At lower temperatures, the competitive adsorption of butylene over hydrogen accounts for a large initial flux penalty.
\end{abstract}

Keywords: palladium membrane; dehydrogenation; butylene; flux-reducing tendency

\section{Introduction}

Alkene production by the catalytic dehydrogenation (DH) of light alkanes is an alternative to conventional heavy hydrocarbon cracking [1,2]. Dehydrogenation is an endothermic equilibrium-limited reaction and is typically performed at elevated temperatures at close to atmospheric pressure. Even at $500{ }^{\circ} \mathrm{C}$, the thermodynamic equilibrium conversion for propane dehydrogenation is less than $20 \%$. Further, the high operating temperature results in large amounts of carbon deposition on the catalyst, which implies the need for a periodic regeneration of the catalytic bed, leading to a complex plant design with multiple reactors, up to $5-8$, in parallel, operating at temperatures between 500 and $600{ }^{\circ} \mathrm{C}$ [2], which is only feasible at large scale [3,4]. Due to the removal of hydrogen from the reaction, membrane reactors have the potential to provide the same conversion and yield of a conventional process while operating at milder conditions [5-24]. This would potentially reduce the level of catalyst deactivation observed in the conventional dehydrogenation of light alkanes. Additionally, downstream separations are simplified, as most of the hydrogen is separated in situ. It should be noted though that appropriate geometrical designs and operating conditions of a packed-bed membrane reactor are key to use the effect of hydrogen permeable membranes on actually obtaining the intended shift of the equilibrium towards more alkylenes [25].

Among all $\mathrm{H}_{2}$-selective membrane types, Pd-based membranes show an optimum match with the operating conditions typically targeted in a membrane-enhanced dehydrogenation process that is potentially operated between 300 and $500{ }^{\circ} \mathrm{C}[26,27]$. One of the most investigated challenges for Pd-based membranes is that they are, to various degrees, prone to poisoning by for example $\mathrm{CO}$ and other surface co-adsorbates, leading to a reduced $\mathrm{H}_{2}$ flux through coking [28-37]. Also in the case of dehydrogenation of light alkenes, it was observed that the obtained $\mathrm{H}_{2}$ flux decreases 
over time $[6,13,15,38,39]$. The most common explanation for the flux decrease is coke formation accumulating on the membrane surface, thereby suppressing the $\mathrm{H}_{2}$ permeation. In a recent study, the evolution of various surface and bulk carbon species derived from propylene and their influence on the hydrogen flux was investigated. Results indicate that there are at least four different carbon species that are deposited onto the $\mathrm{Pd}$ foil during $\mathrm{C}_{3} \mathrm{H}_{6}$ exposure [40]. Primarily, the surface-adsorbed $\mathrm{C}_{\mathrm{x}} \mathrm{H}_{\mathrm{y}}$ species are responsible for the $\mathrm{H}_{2}$ flux inhibition, but it is shown that their structure evolves to become subsurface or even bulk carbon species with increasing exposure time, concentration, and temperature. At temperatures below $300-400{ }^{\circ} \mathrm{C}$, bulk $\mathrm{C}$ species are not formed due to the large activation barrier for $\mathrm{C}$ diffusion in the bulk of Pd. The results presented in [40] agree well with our previous work investigating the effect of propylene on hydrogen permeation through thin state-of-the-art $\mathrm{Pd}-\mathrm{Ag}$ and $\mathrm{Pd}-\mathrm{Cu}$ alloy membranes [39]. In that work, with the specific aim to investigate operating conditions that result in a negligible flux reduction, a wide range of operating conditions, such as temperature and $\mathrm{H}_{2}$ /propylene ratio, were investigated. It was shown that coking could be limited at lower operating temperature, and a decrease to at least $300{ }^{\circ} \mathrm{C}$ or, preferably, to $250{ }^{\circ} \mathrm{C}$ is required to achieve sufficiently stable membrane operation in the conditions observed in a non-integrated sequential reactor-membrane process design [41]. In the sequential reactor-membrane process, a stable membrane performance was obtained at $200{ }^{\circ} \mathrm{C}$ at hydrogen recover factor (HRF) values varying from 38 to 50\% [39].

In the present work, we report a thorough investigation of the effect of butane and butylene on hydrogen permeation through thin Pd-Ag alloy membranes. The effects of a wide range of operating conditions, such as temperature and $\mathrm{H}_{2}$ /butylene/butane ratio, on the flux-reducing tendency were investigated. In addition, the behavior of membrane performance during prolonged exposure to butylene was evaluated. Finally, the long-term stability of the membrane itself was investigated and characterized through a post-process characterization of applied membranes. As in previous works, experiments were conducted using thin state-of-the-art self-standing Pd-Ag foils integrated in a microchannel-configured module. This configuration is very well suited for the investigation of surface inhibition effects caused by co-existing species in the gaseous feed under different operating conditions in the absence of any flux-limiting factors such as concentration polarization [42,43].

\section{Materials and Methods}

\subsection{Pd Alloy Module Preparation}

$\mathrm{Pd}$ alloy films were prepared by magnetron sputtering from a $\mathrm{Pd}_{77} \mathrm{Ag}_{23}$ target onto a silicon substrate, and subsequently integrated in a microchannel configuration to allow for hydrogen permeation measurements. Membrane films with a nominal thickness of 10 micron were applied in the current work. The microchannel system applied in this work consisted of a stainless steel feed channel section with thirteen parallel channels machined with dimensions $0.2 \times 0.2 \times 13 \mathrm{~mm}^{3}$, and is similar to the module applied in our previous work on propylene $[39,44]$. On the permeate side of the membrane, a perforated steel support plate was mounted. In total, the thirteen channels provided for a $0.449 \mathrm{~cm}^{2}$ active membrane area. The $\mathrm{Pd}_{77} \mathrm{Ag}_{23}$ film-loaded membrane module was then connected to the gas system to allow for flux measurements. Two membrane modules were applied during the investigation.

\subsection{Gas Permeation Measurements}

\subsection{1. $\mathrm{H}_{2}$ Permeation Experiments}

The $\mathrm{H}_{2}$ permeation system reported previously in $[39,45,46]$ was used for the permeation and exposure experiments. When heating up the module, the membrane was flushed with $\mathrm{N}_{2}(99.999 \%)$ and $\operatorname{Ar}(99.999 \%)$ on the feed and permeate side, respectively, until $300{ }^{\circ} \mathrm{C}$ was reached. $\mathrm{Then}_{2}$ (99.995\%) was introduced at the feed side. $\mathrm{H}_{2}$ flux measurements were performed in the temperature range $450-300{ }^{\circ} \mathrm{C}$. The total feed flow rate applied for all measurements equals $500 \mathrm{NmL} \cdot \mathrm{min}^{-1}$. 
Based on previous experience, this feed flow rate is sufficient to suppress the effect of $\mathrm{H}_{2}$ depletion along the microchannel system. A sweep flow of 250 or $500 \mathrm{NmL} \cdot \mathrm{min}^{-1}$ of $\mathrm{Ar}(99.999 \%)$ was applied at the permeate side. The $\mathrm{H}_{2}$ flux was calculated from the measured hydrogen concentration in the permeate using the calibrated flow of Ar sweep gas. For this, the permeate composition was measured by means of a micro GC ( $\mu$ GC, Agilent 490, Santa Clara, CA, USA). The hydrogen permeance was calculated by dividing the hydrogen flux by the hydrogen partial pressure difference $\left(P_{H_{2}^{\text {ret }}}^{0.5}-P_{H_{2}^{\text {perm }}}^{0.5}\right)$ over the membrane. The nominal membrane thickness of 10 micron was used in the calculation of the $\mathrm{H}_{2}$ permeability.

\subsection{2. $\mathrm{H}_{2}$ Permeation Experiments}

The effect of butane and butylene on the $\mathrm{H}_{2}$ flux was investigated applying feed mixtures originally consisting of $\mathrm{H}_{2}$ in $\mathrm{N}_{2}$. Butane or butylene were then introduced by simply exchanging a part of $\mathrm{N}_{2}$. In this way, the feed $\mathrm{H}_{2}$ concentration was kept constant. In between different exposure studies, the membrane was regenerated applying a heat treatment in air (HTA). The HTA of the membrane surface recovers the $\mathrm{H}_{2}$ flux to its original value $[38,40]$. The HTA treatment was carried out by opening the module connections after flushing with nitrogen and argon, allowing air to enter the module at $400^{\circ} \mathrm{C}$ for $1 \mathrm{~h}$. Afterwards, the connections were re-connected followed by sufficient flushing with nitrogen and argon prior to $\mathrm{H}_{2}$ introduction.

\subsubsection{Post-Process Characterization}

The plan-view and cross-section microstructure of the employed membrane film were characterized after the permeation experiments by scanning electron microscopy (SEM) using secondary electrons (SE) or backscattered electrons (BSE), with an FEI 650 NOVA NanoSEM instrument (FEI Company, Hillsboro, OR, USA) combined with energy dispersive spectroscopy (EDS) (X-MAX50, Oxford Instruments, Abingdon, Oxfordshire, UK).

\section{Results and Discussion}

\section{1. $\mathrm{H}_{2}$ Permeation Properties of Employed Pd-Based Membranes}

$\mathrm{H}_{2}$ permeation measurements through the 10 micron-thick $\mathrm{Pd}_{77} \mathrm{Ag}_{23}$ membranes were performed between 300 and $450{ }^{\circ} \mathrm{C}$ applying a feed mixture of $\mathrm{H}_{2}: \mathrm{N}_{2}=80: 20$ at atmospheric pressure. The results for the $\mathrm{H}_{2}$ flux and calculated permeability can be seen in Figure 1 for the first module employed in the experiments.

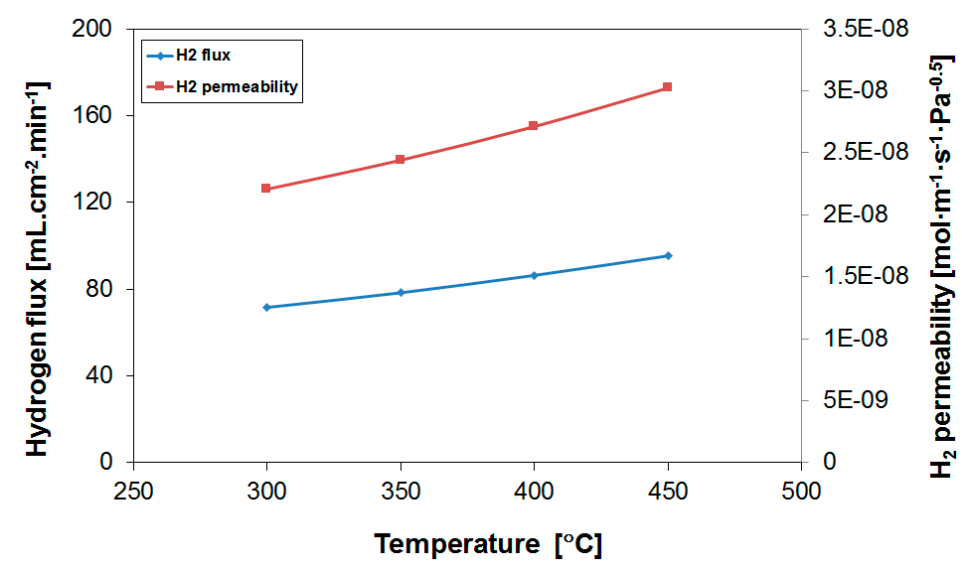

Figure 1. Hydrogen flux and permeability as a function of temperature for the $\mathrm{Pd}_{77} \mathrm{Ag}_{23}$ alloy membrane. Feed: $80 \% \mathrm{H}_{2}$ in $\mathrm{N}_{2}$. 
A hydrogen flux of $95.4 \mathrm{~mL} \cdot \mathrm{cm}^{-2} \cdot \mathrm{min}^{-1}$ was obtained at a temperature of $450{ }^{\circ} \mathrm{C}$. Given the experimental conditions, this corresponds to a hydrogen permeability of $3.0 \times 10^{-8} \mathrm{~mol} \cdot \mathrm{m}^{-1} \cdot \mathrm{s}^{-1} \cdot \mathrm{Pa}^{-0.5}$. The flux and permeability values obtained are shown in Table 1 as a function of the operation temperature. In the calculation of the permeability, the $n$-value was forced to 0.5 . The activation energy of the permeation equals $7.2 \mathrm{~kJ} \cdot \mathrm{mol}^{-1}$, close to reported values for $\mathrm{Pd}_{77} \mathrm{Ag}_{23}$ membranes [47]. Previous reported values for $\mathrm{Pd}_{77} \mathrm{Ag}_{23}$ membranes prepared by the same method are in the range of $8 \times 10^{-9}-3.2$ $\times 10^{-8} \mathrm{~mol} \cdot \mathrm{m}^{-1} \cdot \mathrm{s}^{-1} \cdot \mathrm{Pa}^{-0.5}\left(400{ }^{\circ} \mathrm{C}\right)$ for membranes with a thickness between 1.4 and $10 \mu \mathrm{m} \mathrm{[45-48],}$ agreeing well with current results.

Table 1. Hydrogen flux and permeability as a function of operation temperature. A membrane thickness of $10 \mu \mathrm{m}$ was used to calculate the permeability.

\begin{tabular}{ccc}
\hline Operation Temperature $\left[{ }^{\circ} \mathbf{C}\right]$ & $\mathbf{H}_{\mathbf{2}}$ Flux $\left[\mathbf{m L} \cdot \mathbf{c m}^{-\mathbf{2}} \cdot \mathbf{m i n}^{\mathbf{- 1}]}\right.$ & $\begin{array}{c}\mathbf{H}_{\mathbf{2}} \text { Permeability } \\
{\left[\mathbf{m o l}_{\mathbf{m}} \cdot \mathbf{m}^{\mathbf{- 1}} \cdot \mathbf{s}^{\mathbf{- 1}} \cdot \mathbf{P a}^{-\mathbf{0 . 5}}\right]}\end{array}$ \\
\hline 450 & 95.4 & $3.0 \cdot 10^{-8}$ \\
400 & 86.4 & $2.7 \cdot 10^{-8}$ \\
350 & 78.4 & $2.4 \cdot 10^{-8}$ \\
300 & 71.7 & $2.2 \cdot 10^{-8}$ \\
\hline
\end{tabular}

\subsection{Exposure to Butane}

The effect of butane on the $\mathrm{H}_{2}$ flux performance was investigated applying a feed mixture of $\mathrm{H}_{2}: \mathrm{C}_{4} \mathrm{H}_{10}: \mathrm{N}_{2}=20: 20: 60$ in order to simulate the butane dehydrogenation process. As in previous experiments with respect to propane [39], initial experiments were performed at $400{ }^{\circ} \mathrm{C}$. Due to the low butane vapor pressure at room temperature, $1.6 \mathrm{bar}$, the exposure was performed at atmospheric pressure. Figure 2 shows the $\mathrm{H}_{2}$ flux during the introduction (process time of $210 \mathrm{~h}$ ) and in presence of $20 \%$ butane, respectively. Note that the obtained $\mathrm{H}_{2}$ flux value is lower compared to the initial results presented in Figure 1 because of the lower $\mathrm{H}_{2}$ feed content.

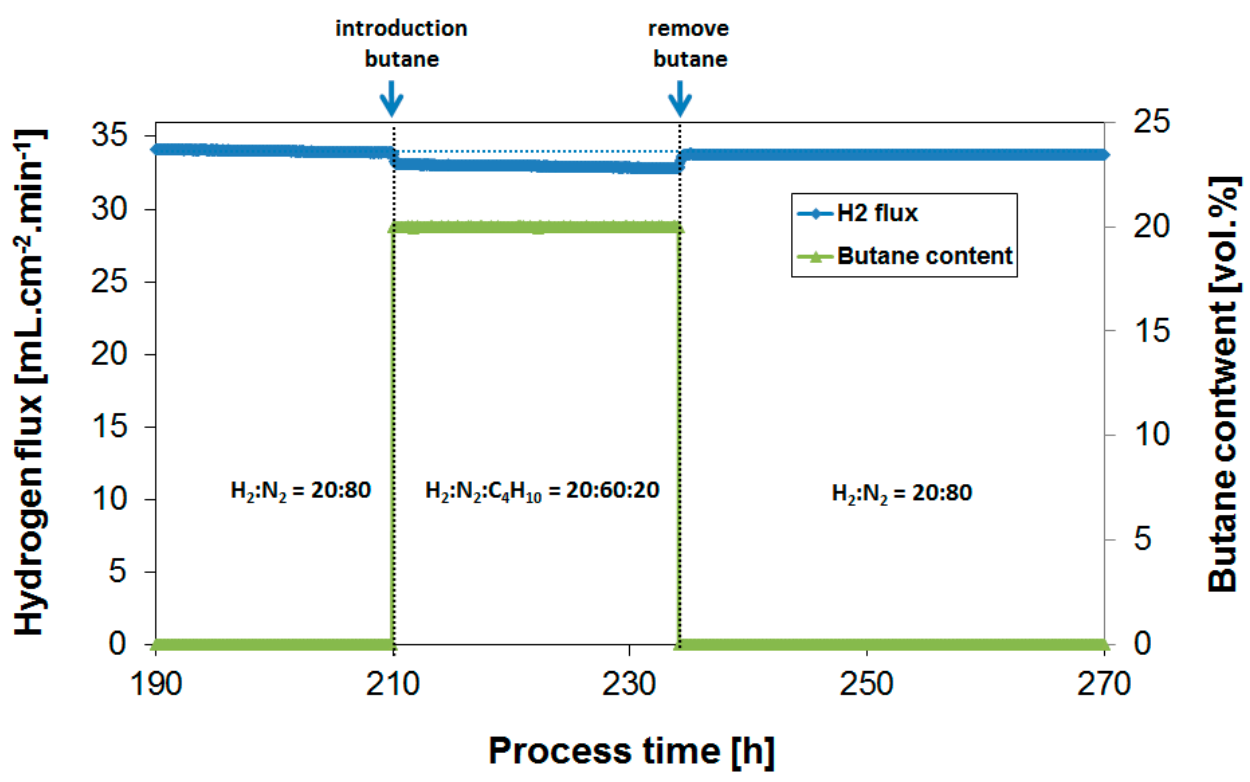

Figure 2. $\mathrm{H}_{2}$ flux during butane introduction (20\%) and overnight exposure to a feed mixture of $\mathrm{H}_{2}: \mathrm{N}_{2}: \mathrm{C}_{4} \mathrm{H}_{10}=20: 60: 20$. Temperature $=400{ }^{\circ} \mathrm{C}$.

The butane introduction resulted in a $\mathrm{H}_{2}$ flux decline of approximately 2-3\%. The slight decrease in flux is presumably explained by a small mismatch in the applied flows, resulting in a minor decrease in $\mathrm{H}_{2}$ feed content upon butane introduction. Most importantly, the continuous exposure for $24 \mathrm{~h}$ to a 
feed of $\mathrm{H}_{2}: \mathrm{N}_{2}: \mathrm{C}_{4} \mathrm{H}_{10}=20: 60: 20$ resulted in a relatively constant $\mathrm{H}_{2}$ flux, showing that the tendency for coke formation in the presence of butane is minimal. The removal of butane (process time of $234 \mathrm{~h}$ ) resulted as well in a complete flux recovery, suggesting that the observed inhibition was governed by a reversible adsorption process, and not by irreversible coke formation that was expected to be removed much slower from the surface. Subsequently, the butane effect was investigated at $450{ }^{\circ} \mathrm{C}$. Figure 3 summarizes obtained $\mathrm{H}_{2}$ flux inhibition curves as a function of temperature plotted as relative $\mathrm{H}_{2}$ flux values at 400 and $450{ }^{\circ} \mathrm{C}$. The relative $\mathrm{H}_{2}$ flux corresponds to the measured $\mathrm{H}_{2}$ flux in the presence of butane normalized by the $\mathrm{H}_{2}$ flux obtained before the butane introduction under otherwise equal conditions of temperature, absolute feed pressure, hydrogen partial pressure and total feed flow rate.

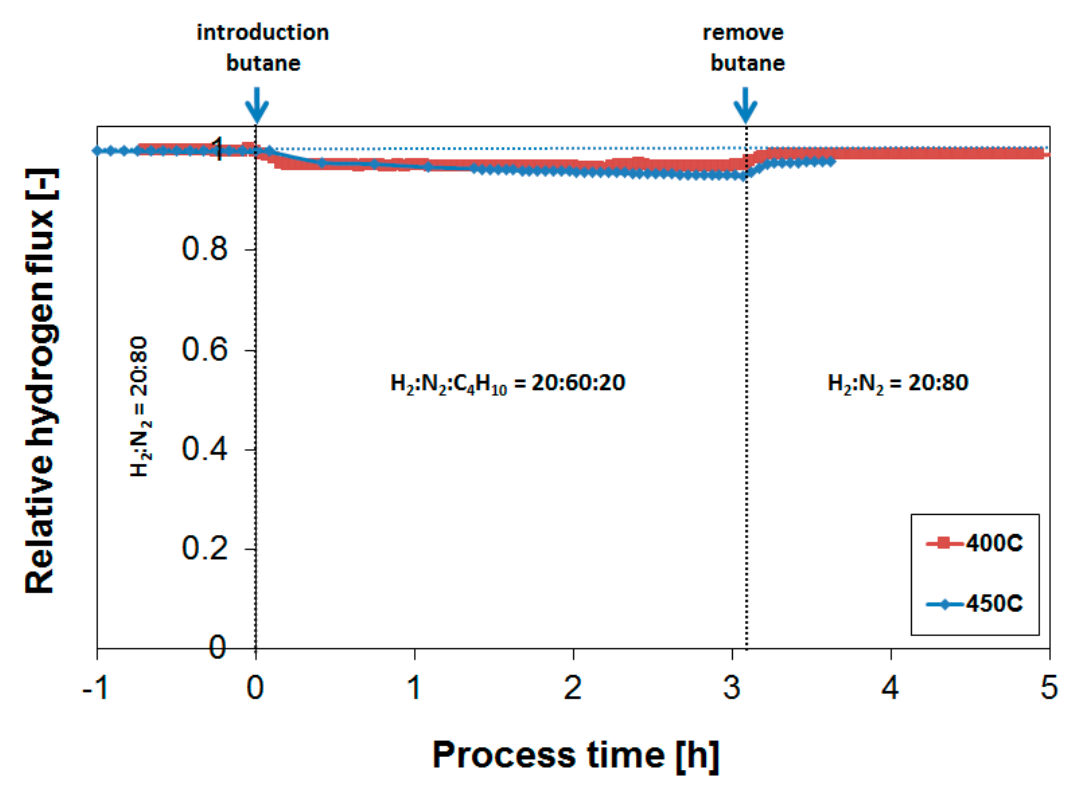

Figure 3. Effect of temperature on the obtained relative $\mathrm{H}_{2}$ flux during butane exposure applying a feed mixture of $\mathrm{H}_{2}: \mathrm{C}_{4} \mathrm{H}_{10}: \mathrm{N}_{2}=20: 20: 60$.

Even though the flux decline was slightly accelerated at higher temperatures, the flux reducing coke formation tendency was still relatively limited at $450{ }^{\circ} \mathrm{C}$. Comparing this limited flux decrease in the presence of butane with previous results for propane [39] shows that the $\mathrm{H}_{2}$ flux reducing tendency for butane was less compared to propane. A similar membrane operated at $450{ }^{\circ} \mathrm{C}$ in a mixture of $\mathrm{H}_{2}: \mathrm{N}_{2}: \mathrm{C}_{3} \mathrm{H}_{8}=30: 20: 50$ shows a gradual $\mathrm{H}_{2}$ flux decrease to a value of approximately $65 \%$ of the original $\mathrm{H}_{2}$ flux after $18 \mathrm{~h}$. It should be noted that the ratio between $\mathrm{H}_{2}$ and the hydrocarbon determines the extent of coke formation. In that respect, a direct comparison is not directly possible, as [39] applied $\mathrm{H}_{2}$ to propane ratio of 0.6. It should also be noted that the operating pressure is not the same either-1 bar versus 4 bar-even though this seemingly does not affect coke formation tendency.

\subsection{Parametric Study of $\mathrm{H}_{2}$ Flux Inhibition During Butylene Exposure}

The effect of butylene on the $\mathrm{H}_{2}$ flux performance was investigated at varying $\mathrm{H}_{2}$ /butylene ratios. For the initial experiments, a temperature of $400{ }^{\circ} \mathrm{C}$ was chosen, similar to the butane experiments described in Section 3.2. Figures 4 and 5 show the $\mathrm{H}_{2}$ flux during exposure to a feed containing 20 or $40 \%$ butylene, respectively, at a $\mathrm{H}_{2}$ content of $20 \%$. It was previously shown that the extent of coke formation is not determined by the absolute propylene concentration, but by the ratio between $\mathrm{H}_{2}$ and propylene $[39,40]$. 


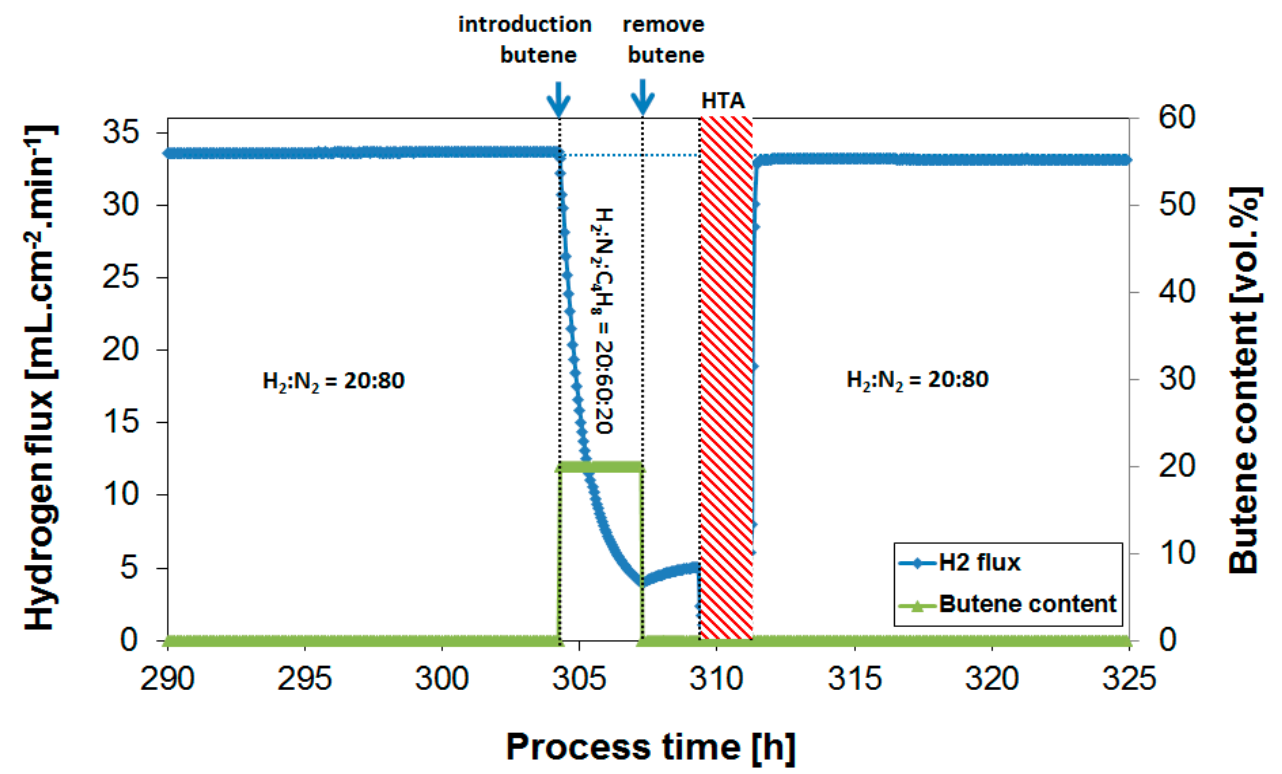

Figure 4. $\mathrm{H}_{2}$ flux during butylene exposure (20\%) to a feed mixture of $\mathrm{H}_{2}: \mathrm{N}_{2}: \mathrm{C}_{4} \mathrm{H}_{10}=20: 60: 20$, and subsequent air treatment to regenerate the membrane performance. Temperature $=400{ }^{\circ} \mathrm{C}$.

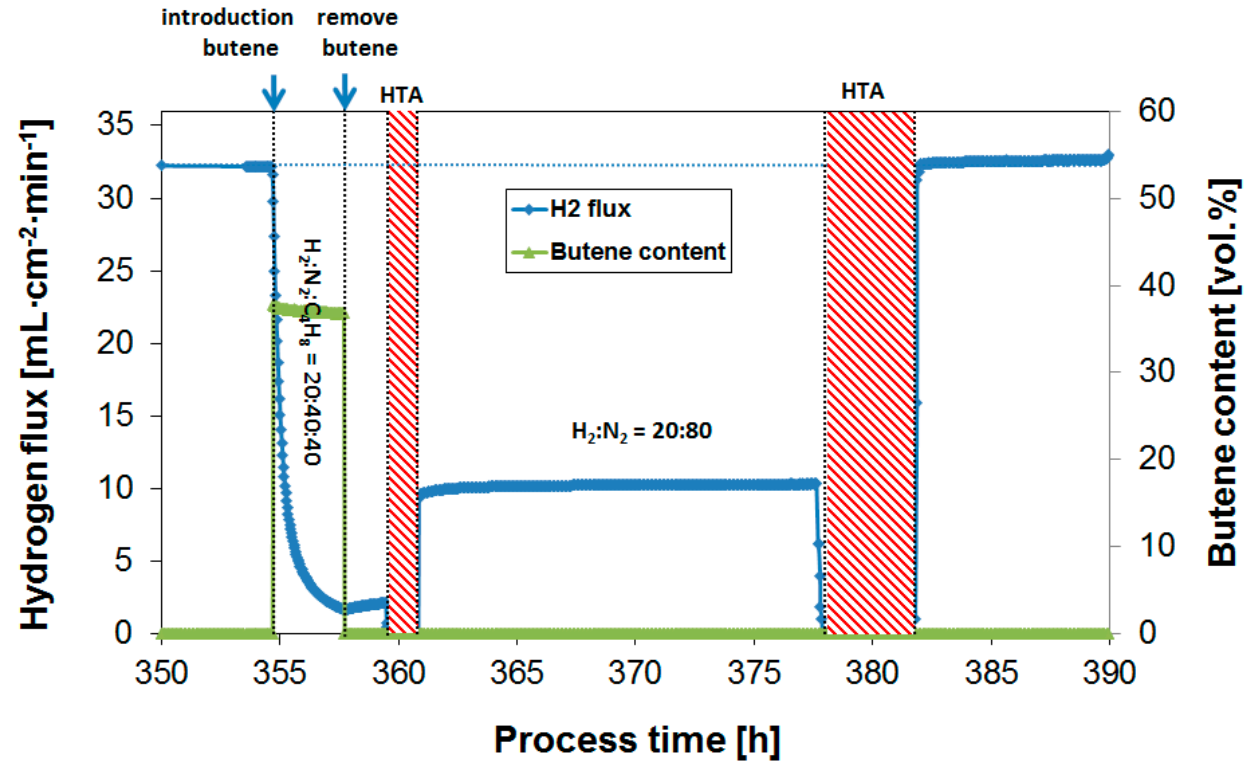

Figure 5. $\mathrm{H}_{2}$ flux during butylene exposure (40\%) to a feed mixture of $\mathrm{H}_{2}: \mathrm{N}_{2}: \mathrm{C}_{4} \mathrm{H}_{10}=20: 40: 40$, and subsequent air treatments to regenerate the membrane performance. Temperature $=400{ }^{\circ} \mathrm{C}$.

Upon butylene exposure, the $\mathrm{H}_{2}$ flux rapidly decreases; in the case of $20 \%$ butylene, the flux dropped by $\sim 85 \%$ after $3 \mathrm{~h}$ of exposure compared to the $\mathrm{H}_{2}$ flux prior to the butylene exposure. This is directly related to the gradual generation of surface-adsorbed $\mathrm{C}_{\mathrm{x}} \mathrm{H}_{\mathrm{y}}$ species or coke formation on the membrane leading to a deactivation of the membrane surface. The large difference in coking tendency between alkanes and alkylenes was reported in an early study by Collins et al. [15] and in our previous work applying the same methodology [39]. This difference is explained by the much larger alkylene adsorption on palladium compared to alkanes, resulting in a higher propylene surface coverage under the same conditions $[49,50]$. Unsaturated species also have a higher tendency to form oligomers and ring structures compared to alkanes. The removal of butylene from the feed stream results in a gradual flux recovery, but, as seen before, a full recovery would not be reached within a reasonable time scale, 
e.g., several hours. Even a continuous exposure to a $\mathrm{H}_{2}$-containing feed in the absence of butylene over a period of $>200 \mathrm{~h}$ at $350{ }^{\circ} \mathrm{C}$ did not result in a substantial recovery of the $\mathrm{H}_{2}$ flux, see Figure 7 . Prior to the next exposure, an oxidative treatment was therefore consistently performed in order to recover the initial $\mathrm{H}_{2}$ flux. The oxidative treatment at the membrane operating temperature removes surface contaminants from the membrane, and thereby reverses the flux decrease [29,40,51]. In the case of severe coke formation, multiple and/or longer treatments in air were found to be required (as shown in, e.g., Figure 5 after coke formation exposing the membrane to a feed gas at a low $\mathrm{H}_{2}$ to butylene ratio). Figure 6 summarizes obtained $\mathrm{H}_{2}$ flux inhibition curves as a function of the $\mathrm{H}_{2} /$ butylene ratio at $400{ }^{\circ} \mathrm{C}$. The results were plotted as a relative flux to allow for a direct comparison of the propene inhibition and coke formation effect obtained at the different ratios.

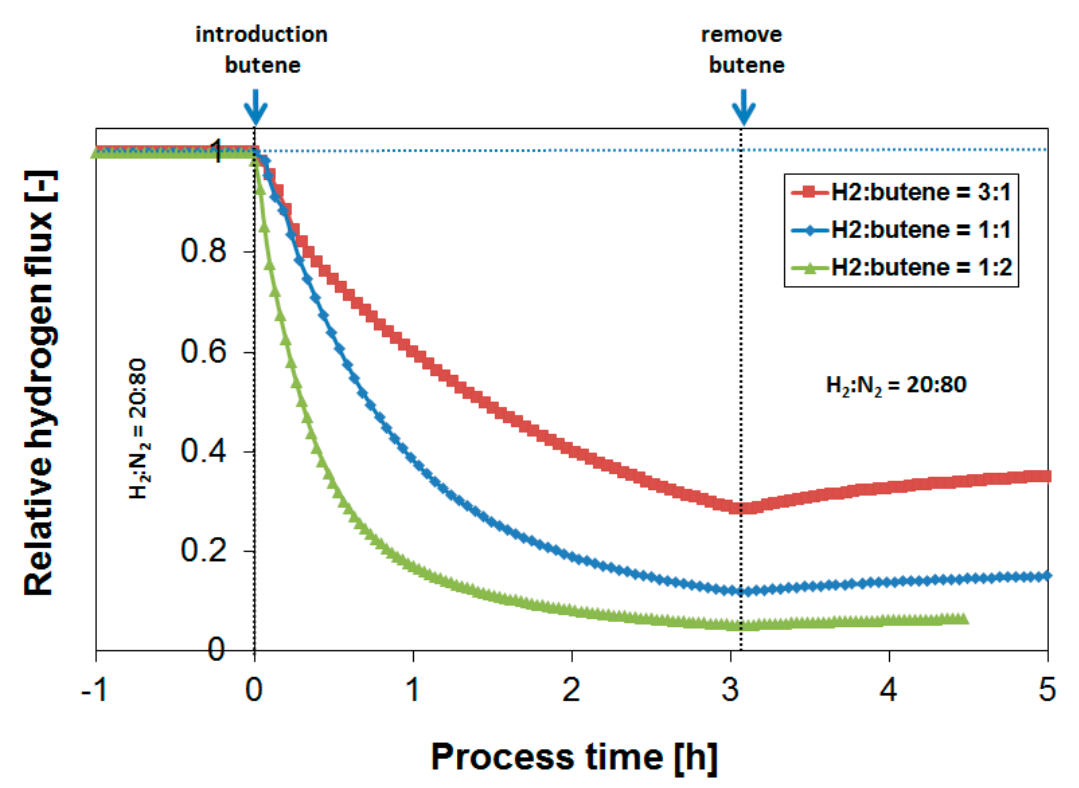

Figure 6. Effect of the $\mathrm{H}_{2}$ /butylene ratio in the membrane feed on the obtained relative $\mathrm{H}_{2}$ flux after the butylene introduction. Temperature $=400^{\circ} \mathrm{C}$.

It is shown that the poisoning effect of butylene generally increases with a decreasing $\mathrm{H}_{2} /$ butylene ratio. It should also be noted that the rate of flux recovery in the absence of butylene is increasing with the $\mathrm{H}_{2}$ /butylene ratio of the performed exposure, which is probably related to the amount of carbon formed during the experiment. This agrees with previous results on propylene [39,40]. In a membrane-enhanced dehydrogenation process, however, at realistic conditions of hydrogen recovery, $\mathrm{H}_{2}$ /butylene ratios of $0.33-0.5$ are typically encountered $[6,23,41]$. From Figure 6 it can be seen that at the $\mathrm{H}_{2}$ /butylene ratio of 0.5 , the $\mathrm{H}_{2}$ flux decreases by approximately $95 \%$ after three hours of exposure, which would not be acceptable from a process point of view. It would thus be required to decrease the membrane temperature in order to prevent coke formation in the presence of butylene. Alternatively, a protective coating can be applied on top of the Pd-based membrane surface to prevent the detrimental gaseous components that are responsible for the flux decrease from reaching the Pd membrane surface $[52,53]$, but this was not part of the current study.

Subsequently, coke formation kinetics were investigated as a function of temperature between 250 and $450{ }^{\circ} \mathrm{C}$ at a fixed $\mathrm{H}_{2}$ /butylene ratio of 1 . Figure 7 shows the $\mathrm{H}_{2}$ flux during butylene exposure to a feed composition of $\mathrm{H}_{2}: \mathrm{N}_{2}: \mathrm{C}_{4} \mathrm{H}_{8}=20: 60: 20$ at $350{ }^{\circ} \mathrm{C}$, while Figure 8 summarizes the obtained $\mathrm{H}_{2}$ flux inhibition curves as a function of temperature, again plotted in relative flux numbers. 


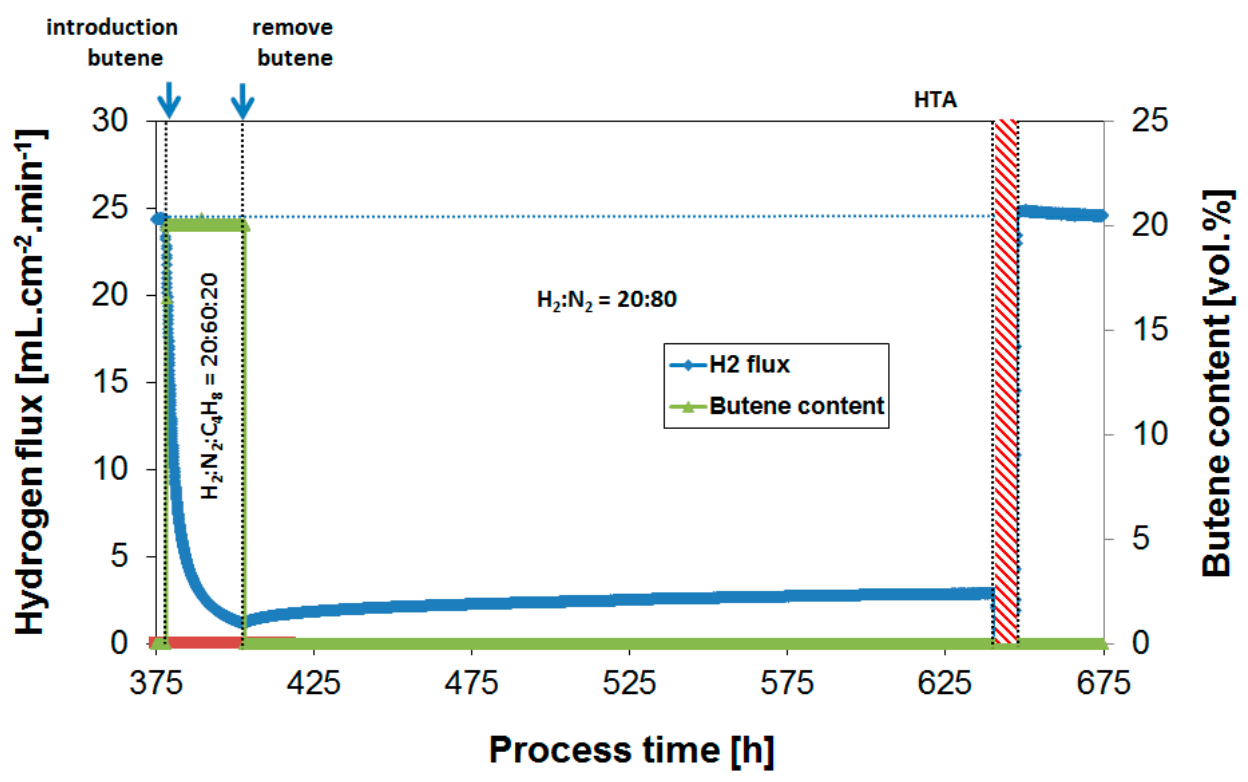

Figure 7. $\mathrm{H}_{2}$ flux during continuous recovery after butylene exposure $(20 \%)$ to a feed mixture of $\mathrm{H}_{2}: \mathrm{N}_{2}: \mathrm{C}_{4} \mathrm{H}_{10}=20: 60: 20$. Subsequent air treatment to regenerate the membrane performance. Temperature $=350{ }^{\circ} \mathrm{C}$.

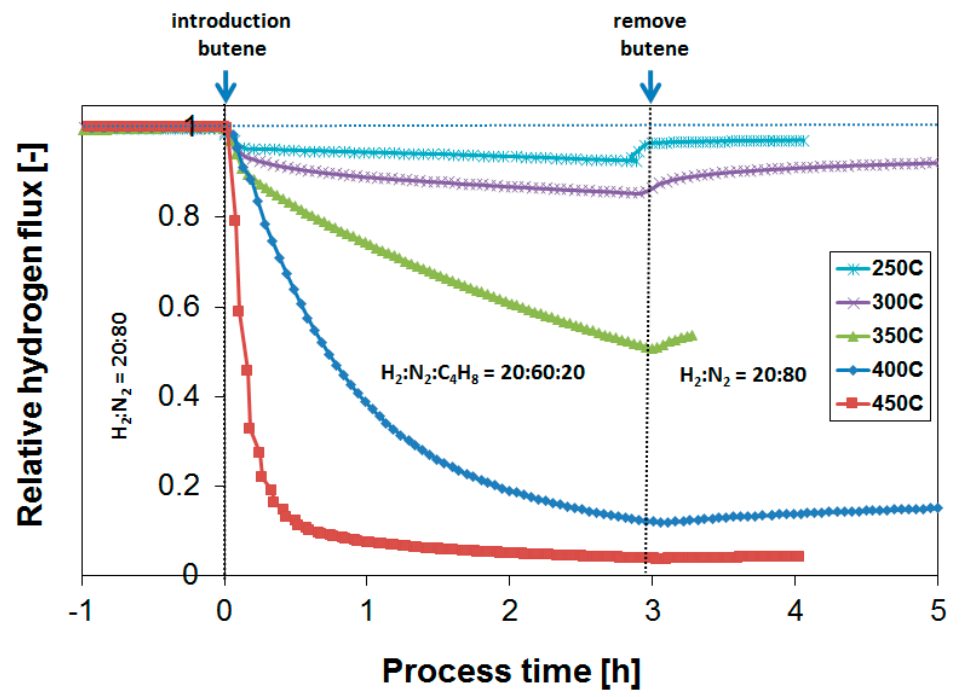

Figure 8. Effect of temperature on the obtained relative $\mathrm{H}_{2}$ flux after butylene introduction. The $\mathrm{H}_{2}$ /butylene ratio is equal to 1 .

Figure 8 shows that the extent of coking decreases rapidly with temperature, and coke formation is rather limited already at $250{ }^{\circ} \mathrm{C}$ under the conditions investigated, leading to stable membrane operation. This is as expected from similar studies with respect to the development of dehydrogenation catalysts [54]. It is thus potentially possible, in a non-integrated sequential reactor/separator process scheme, to operate the membrane module at a lower temperature than the dehydrogenation reactor, thereby allowing for stable membrane operation. In terms of the absolute attainable $\mathrm{H}_{2}$ flux, the negative effect of this temperature decrease is very limited due to the low activation energy of permeation. Moreover, the produced $\mathrm{H}_{2}$ might even be applied to heat the incoming feed stream to the next dehydrogenation reactor. However, to investigate whether these operating conditions allow for sufficiently stable membrane operation, which preferably matches the lifetime of the catalyst system, long-term exposures were investigated. 


\subsection{Long-Term Performance During Butylene Exposure}

The behavior of membrane performance over prolonged exposure to butylene ( $24 \mathrm{~h}$ instead of $3 \mathrm{~h}$ ) at $250{ }^{\circ} \mathrm{C}$ is reported in Figure 9. Even though coke formation in the short term is rather limited already at $250{ }^{\circ} \mathrm{C}$ (Figure 8), the prolonged exposure to the same temperature leads to drastically reduced $\mathrm{H}_{2}$ fluxes. After $24 \mathrm{~h}$, the $\mathrm{H}_{2}$ flux decreased to a value of approximately $30 \%$ of the original $\mathrm{H}_{2}$ flux.

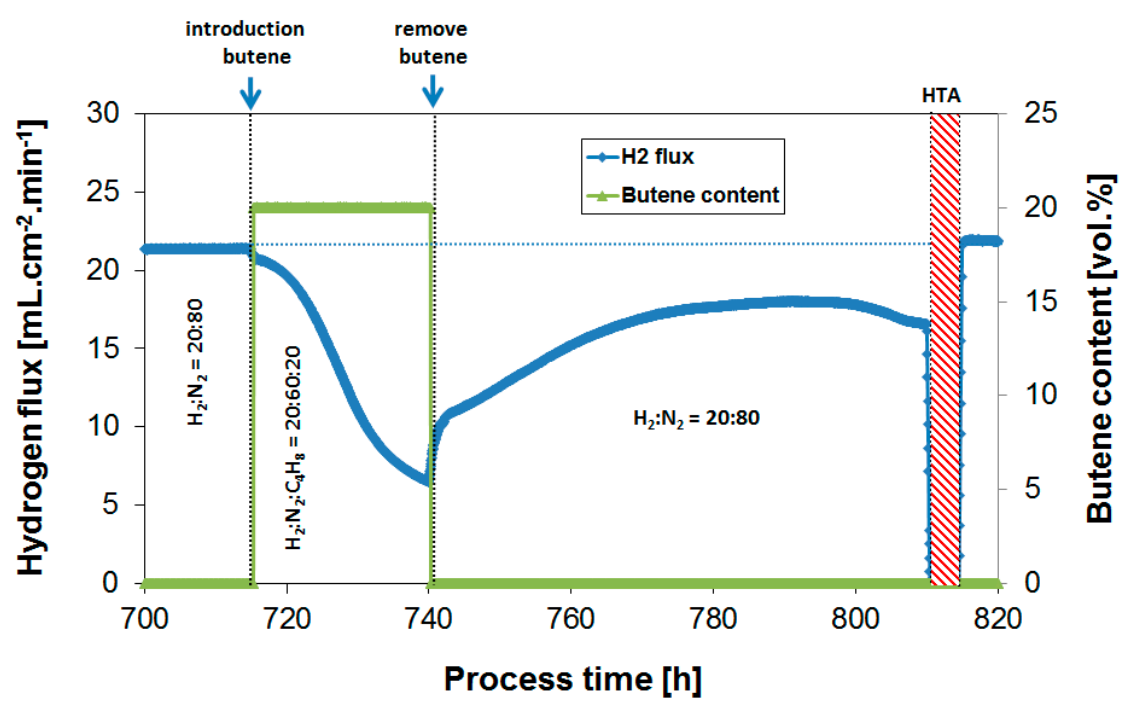

Figure 9. $\mathrm{H}_{2}$ flux during prolonged exposure to butylene $(20 \%)$ in a feed containing: $\mathrm{H}_{2}: \mathrm{N}_{2}: \mathrm{C}_{4} \mathrm{H}_{10}=20: 60: 20$. Subsequent air treatment to regenerate the membrane performance. Temperature $=250^{\circ} \mathrm{C}$.

Figure 10 summarizes obtained $\mathrm{H}_{2}$ flux inhibition curves as a function of temperature plotted as relative flux numbers. A further decrease to $200{ }^{\circ} \mathrm{C}$ did not improve the membrane operability. On the contrary, even though coke formation tendency in itself was lowered with temperature, the competitive adsorption of butylene with respect to hydrogen accounted for a large initial flux penalty. This is visualized by the large immediate flux decrease directly after butylene introduction for the exposure at $200{ }^{\circ} \mathrm{C}$. A similar initial flux decrease due to absorption is not visible at higher temperatures.

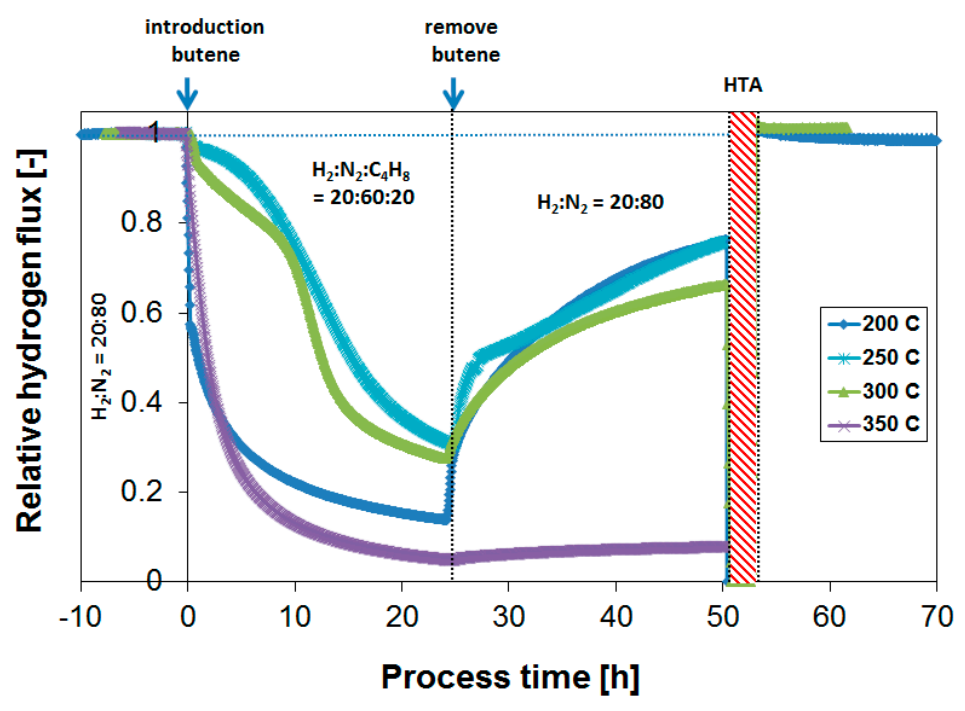

Figure 10. Effect of temperature on the obtained relative $\mathrm{H}_{2}$ flux during prolonged butylene exposure. $\mathrm{H}_{2}: \mathrm{N}_{2}: \mathrm{C}_{4} \mathrm{H}_{10}=20: 60: 20$. 
In terms of operating temperature, an optimal temperature was thus found at $250-300{ }^{\circ} \mathrm{C}$ with respect to obtaining the highest absolute hydrogen flux in the presence of butylene. The same can be concluded from the flux recovery in the absence of any butylene. Whereas the flux decrease that occurred during the exposure at $350{ }^{\circ} \mathrm{C}$ was persistent, the flux decrease due to the surface $\mathrm{C}_{\mathrm{x}} \mathrm{H}_{\mathrm{y}}$ species or coke formed at lower temperatures was recovered at a higher rate. This suggests that more persistent poisoning species form at temperatures $>300^{\circ} \mathrm{C}$, which may include various surface species and subsurface carbon [40].

\subsection{Membrane Stability}

\subsubsection{Separation Performance}

Figure 11 shows the performance of membrane module 1 during nearly $1600 \mathrm{~h}$ of operation during which the module was operated up to $450{ }^{\circ} \mathrm{C}$ and 4 bars, respectively. During the operation, the module went through two start-up and shut-down cycles and was exposed to air at elevated temperatures for a total of 15 times to regenerate the performance after hydrocarbon exposure.

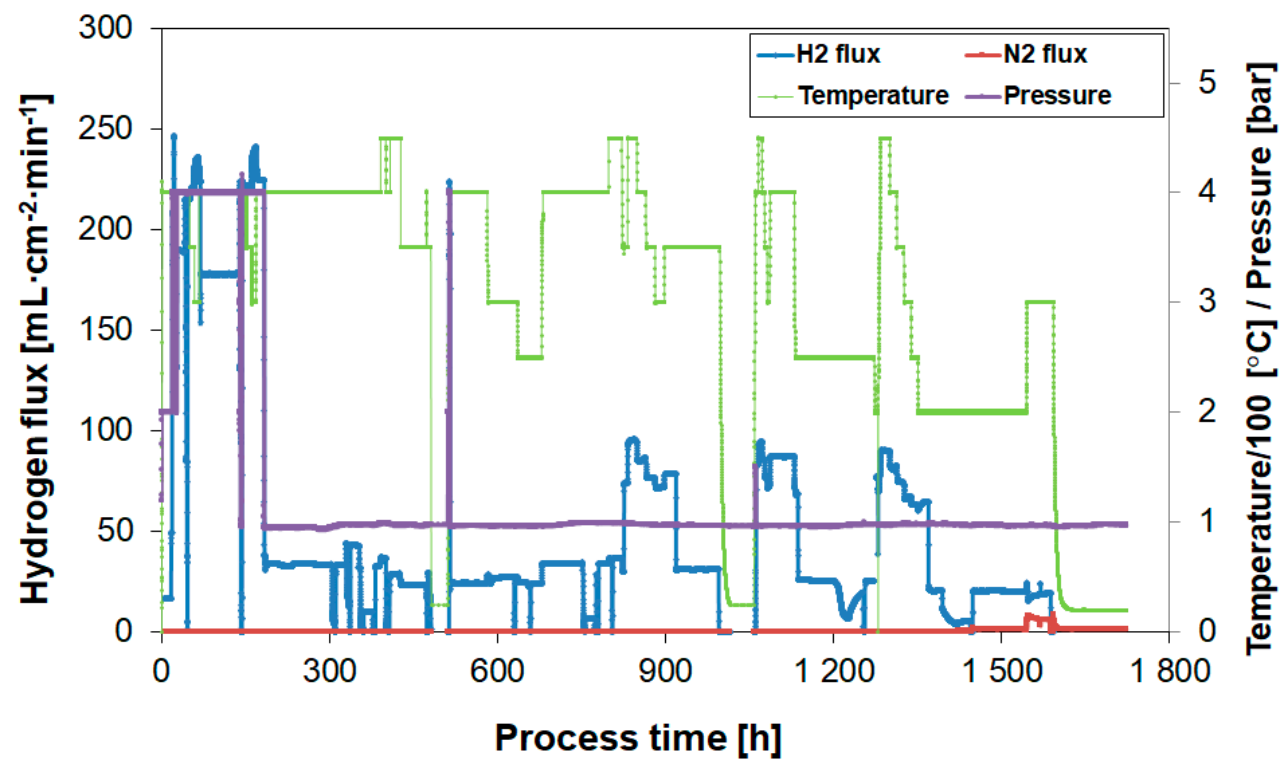

Figure 11. Membrane module \#1; $1600 \mathrm{~h}$ operation up to $450{ }^{\circ} \mathrm{C}$ and 4 bars.

During the initial $1500 \mathrm{~h}$ of testing, no unselective flow of $\mathrm{N}_{2}$ was observed, showing that the membrane was $100 \%$ selective to $\mathrm{H}_{2}$. However, after approximately $1600 \mathrm{~h}$, during the evaluation of the butylene effect at $200{ }^{\circ} \mathrm{C}$, the membrane started to leak, as indicated by the appearance of $\mathrm{N}_{2}$ on the permeate side of the membrane. The module was then cooled down and made available for post-process characterization. A new membrane module was prepared for the longer-term exposure experiments to butylene as described in Section 3.4. This second module was operated for nearly $1000 \mathrm{~h}$ and kept $100 \%$ selective to hydrogen throughout the test.

\subsubsection{Post-Process Membrane Characterization}

SEM micrographs of the feed and permeate surface of the tested membrane (module \#1) are shown in Figure 12. Figure 12a,d clearly shows the imprint of microchannels across the $\operatorname{Pd}_{77} \mathrm{Ag}_{23}$ film. This is due to plastic deformation of the thin film into the channel support during the higher-pressure operation, as previously reported in [55]. 

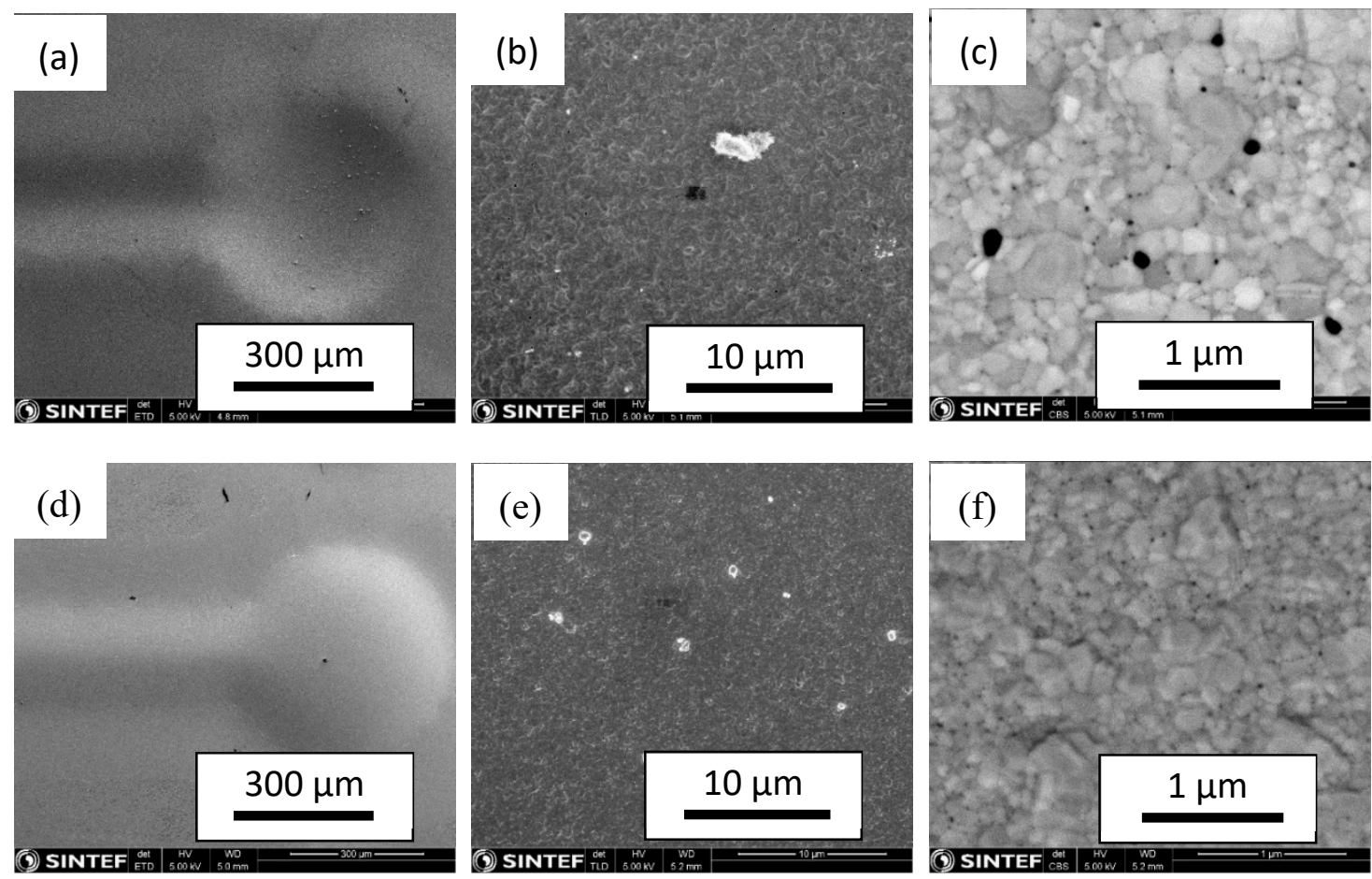

Figure 12. SEM images of the $\operatorname{Pd}_{77} \mathrm{Ag}_{23}$ film after testing: $(\mathbf{a}-\mathbf{c})$ feed (growth side) and $(\mathbf{d}-\mathbf{f})$ permeate (silicon side), at different magnifications.

After $1600 \mathrm{~h}$ of operation, the feed and permeate sides had a fairly similar grain size, approximately 200-400 nm, which is different from the initial untreated membrane with much smaller grains at the permeate side [46]. Grains with a similar size were observed after long-term operation of a $\mathrm{Pd}_{77} \mathrm{Ag}_{23}$ membrane in the absence of any butylene, though over a period of 100 days at up to 20 bar and $450{ }^{\circ} \mathrm{C}$ [56]. Thus, the grain growth cannot be clearly linked to the butylene exposure and is most probably simply linked to the high-temperature operation of these types of membranes [57]. An analysis of the two respective sides of the membrane by energy dispersive X-ray spectroscopy (EDS) shows a higher level of carbon on the feed side of the membrane, supporting previous results concluding that the gradual decrease in $\mathrm{H}_{2}$ flux during alkene exposure is due to coke formation on the membrane surface.

Figure $12 \mathrm{c}, \mathrm{f}$ show as well that pinholes have developed over the long-term testing of the membrane. The development of pinholes is likely to be linked to structural changes resulting from temperature, strain and chemical potential gradients, grain growth and grain boundary deformation in particular. The largest pinholes have a diameter of approximately $50-100 \mathrm{~nm}$, but both Figure 12c,f show a high density of much smaller pinholes that are primarily located at the grain boundaries. Previous work and on-going research show that Pd-based membranes develop cavities along the grain boundaries [58-60]. These cavities may represent initial stages of pinhole formation, which lead to unselective leakage and compromise the long-term stability of the membranes. It should also be noted that the current film went through 15 exposures to air at high temperatures to regenerate the performance after hydrocarbon exposure. As shown previously [51,61,62], air-treated membranes can develop structural changes, i.e., void formation and surface roughening, during an oxidation-reduction cycle. For the current membranes, it can thus also be that the pinhole formation is simply related to the multiple heat treatment procedures in air, even though other processes generating defects cannot be ruled out.

\section{Conclusions}

The hydrogen flux characteristics of a $\mathrm{Pd}-\mathrm{Ag}$ membrane were evaluated for hydrogen/ butane/butylene feed gas mixtures. We report the effect of a wide range of operating conditions, such 
as temperature (200-450 ${ }^{\circ} \mathrm{C}$ ) and $\mathrm{H}_{2} /$ butylene (or butane) ratio (0.5-3), on coke formation kinetics. In the presence of butane, the flux-reducing tendency was found to be limited up to the maximum temperature investigated, $450{ }^{\circ} \mathrm{C}$. Compared to butane, the flux-reducing tendency in the presence of butylene was severe. At $400{ }^{\circ} \mathrm{C}$ and $20 \%$ butylene, the flux decreases by $\sim 85 \%$ after $3 \mathrm{~h}$ of exposure, but it is shown that the decrease depends on temperature and the $\mathrm{H}_{2}$ /butylene ratio. In terms of operating temperature, an optimal temperature was found at $250-300{ }^{\circ} \mathrm{C}$ with respect to obtaining the highest absolute hydrogen flux in the presence of butylene. At lower temperatures, the competitive adsorption of butylene over hydrogen accounts for a large initial flux penalty. Whereas the flux decrease that occurred during the exposure at $350^{\circ} \mathrm{C}$ was persistent, the flux decrease observed at lower temperatures was recovered at a higher rate. This suggests that more persistent poisoning species form at temperatures $>300^{\circ} \mathrm{C}$, which may include various surface species and subsurface carbon. The experimental sequence was performed applying two membrane modules over a period of 110 days $(\sim 2500 \mathrm{~h})$ during which the membranes were operated up to temperature of $450{ }^{\circ} \mathrm{C}$, and pressure up to 4 bars. A tendency of nano-size pore formation was observed by post-process SEM characterization.

Author Contributions: Conceptualization, T.A.P. and M.S.; Methodology, T.P., M.S., and R.B.; Investigation, T.A.P.; Resources, T.A.P.; Writing-Original Draft Preparation, T.A.P. and M.S.; Writing-Review and Editing, T.A.P., M.S. and R.B.; Visualization, T.A.P.; Project Administration, T.A.P.; Funding Acquisition, T.A.P. All authors have read and agreed to the published version of the manuscript.

Funding: This research received funding from the European Union's Horizon 2020 Research and Innovation Program (H2020) under grant agreement ID: 814671, “Bifunctional Zeolite based Catalysts and Innovative process for Sustainable Hydrocarbon Transformation" (BIZEOLCAT).

Acknowledgments: We acknowledge Martin Fleissner Sunding for the post-process SEM characterization.

Conflicts of Interest: The authors declare no conflict of interest. The funders had no role in the design of the study; in the collection, analyses, or interpretation of data; in the writing of the manuscript, and in the decision to publish the results.

\section{References}

1. James, O.O.; Mandal, S.; Alele, N.; Chowdhury, B.; Maity, S. Lower alkanes dehydrogenation: Strategies and reaction routes to corresponding alkenes. Fuel Process. Technol. 2016, 149, 239-255. [CrossRef]

2. Sattler, J.J.H.B.; Ruiz-Martinez, J.; Santillan-Jimenez, E.; Weckhuysen, B.M. Catalytic Dehydrogenation of Light Alkanes on Metals and Metal Oxides. Chem. Rev. 2014, 114, 10613-10653. [CrossRef] [PubMed]

3. Caspary, K.J.; Gehrke, H.; Heinrita-Adrian, M.; Schwefer, M. Dehydrogenation of Alkanes. In Handbook of Heterogeneous Catalysis; Wiley-VCH Verlag GmbH \& Co. KGaA: Weinheim, Germany, 2008.

4. Sheintuch, M. and Simakov, D.S.A. Alkanes Dehydrogenation, in Membrane Reactors for Hydrogen Production Processes; Falco, M.D.D., Marrelli, L., Iaquaniello, G., Eds.; Springer: London, UK, 2011; pp. 183-200.

5. Chang, J.S.; Roh, H.S.; Park, M.S.; Park, S.E. Propane dehydrogenation over a hydrogen permselective membrane reactor. Bull. Korean Chem. Soc. 2002, 23, 674-678.

6. Ricca, A.; Montella, F.; Iaquaniello, G.; Palo, E.; Salladini, A.; Palma, V. Membrane assisted propane dehydrogenation: Experimental investigation and mathematical modelling of catalytic reactions. Catal. Today 2019, 331, 43-52. [CrossRef]

7. Liang, W.; Hughes, R. The catalytic dehydrogenation of isobutane to isobutene in a palladium/silver composite membrane reactor. Catal. Today 2005, 104, 238-243. [CrossRef]

8. Moparthi, A.; Uppaluri, R.; Gill, B. Economic feasibility of silica and palladium composite membranes for industrial dehydrogenation reactions. Chem. Eng. Res. Des. 2010, 88, 1088-1101. [CrossRef]

9. Quicker, P.; Höllein, V.; Dittmeyer, R. Catalytic dehydrogenation of hydrocarbons in palladium composite membrane reactors. Catal. Today 2000, 56, 21-34. [CrossRef]

10. Dittmeyer, R.; Höllein, V.; Daub, K. Membrane reactors for hydrogenation and dehydrogenation processes based on supported palladium. J. Mol. Catal. A Chem. 2001, 173, 135-184. [CrossRef]

11. Zhao, R.; Govind, R.; Itoh, N. Studies on Palladium Membrane Reactor for Dehydrogenation Reaction. Sep. Sci. Technol. 1990, 25, 1473-1488. [CrossRef] 
12. Ali, J.K.; Newson, E.; Rippin, D. Exceeding equilibrium conversion with a catalytic membrane reactor for the dehydrogenation of methylcyclohexane. Chem. Eng. Sci. 1994, 49, 2129-2134. [CrossRef]

13. Ali, J.K.; Newson, E.; Rippin, D. Deactivation and regeneration of Pd Ag membranes for dehydrogenation reactions. J. Membr. Sci. 1994, 89, 171-184. [CrossRef]

14. Itoh, N. Limiting conversions of dehydrogenation in palladium membrane reactors. Catal. Today 1995, 25, 351-356. [CrossRef]

15. Collins, J.P.; Schwartz, R.W.; Sehgal, R.; Ward, T.L.; Brinker, C.J.; Hagen, G.P.; Udovich, C.A. Catalytic Dehydrogenation of Propane in Hydrogen Permselective Membrane Reactors. Ind. Eng. Chem. Res. 1996, 35, 4398-4405. [CrossRef]

16. Sheintuch, M.; Dessau, R.M. Observations, modeling and optimization of yield, selectivity and activity during dehydrogenation of isobutane and propane in a Pd membrane reactor. Chem. Eng. Sci. 1996, 51, 535-547. [CrossRef]

17. Hermann, C.; Quicker, P.; Dittmeyer, R. Mathematical simulation of catalytic dehydrogenation of ethylbenzene to styrene in a composite palladium membrane reactor. J. Membr. Sci. 1997, 136, 161-172. [CrossRef]

18. Yildirim, Y.; Gobina, E.; Hughes, R. An experimental evaluation of high-temperature composite membrane systems for propane dehydrogenation. J. Membr. Sci. 1997, 135, 107-115. [CrossRef]

19. She, Y.; Han, J.; Ma, Y. Palladium membrane reactor for the dehydrogenation of ethylbenzene to styrene. Catal. Today 2001, 67, 43-53. [CrossRef]

20. Keuler, J.N. The dehydrogenation of 2-butanol in a Pd-Ag membrane reactor. J. Membr. Sci. 2002, 202, 17-26. [CrossRef]

21. Farsi, M.; Jahanmiri, A.; Rahimpour, M. Simultaneous isobutane dehydrogenation and hydrogen production in a hydrogen-permselective membrane fixed bed reactor. Theor. Found. Chem. Eng. 2014, 48, 799-805. [CrossRef]

22. Wunsch, A.; Mohr, M.; Pfeifer, P. Intensified LOHC-Dehydrogenation Using Multi-Stage Microstructures and Pd-Based Membranes. Membranes 2018, 8, 112. [CrossRef]

23. Ricca, A.; Palma, V.; Iaquaniello, G.; Palo, E.; Salladini, A.A. Highly selective propylene production in a membrane assisted catalytic propane dehydrogenation. Chem. Eng. J. 2017, 330, 1119-1127. [CrossRef]

24. Palo, E.; Salladini, A.A.; Morico, B.; Palma, V.; Ricca, A.; Iaquaniello, G. Application of Pd-Based Membrane Reactors: An Industrial Perspective. Membranes 2018, 8, 101. [CrossRef] [PubMed]

25. Dittrich, C.J. The role of heat transfer on the feasibility of a packed-bed membrane reactor for propane dehydrogenation. Chem. Eng. J. 2020, 381, 122492. [CrossRef]

26. Paglieri, S.N.; Way, J.D. INNOVATIONS IN PALLADIUM MEMBRANE RESEARCH. Sep. Purif. Methods 2002, 31, 1-169. [CrossRef]

27. Ockwig, N.W.; Nenoff, T.M. Membranes for Hydrogen Separation. Chem. Rev. 2010, 110, 2573-2574. [CrossRef]

28. Peters, T.; Stange, M.; Klette, H.; Bredesen, R. High pressure performance of thin Pd-23\%Ag/stainless steel composite membranes in water gas shift gas mixtures; influence of dilution, mass transfer and surface effects on the hydrogen flux. J. Membr. Sci. 2008, 316, 119-127. [CrossRef]

29. Mejdell, A.L.; Jondahl, M.; Peters, T.A.; Bredesen, R.; Venvik, H.J. Effects of $\mathrm{CO}$ and $\mathrm{CO}_{2}$ on hydrogen permeation through a $\sim 3 \mu \mathrm{m} \mathrm{Pd} / \mathrm{Ag} 23 \mathrm{wt} \%$ membrane employed in a microchannel membrane configuration. Sep. Purif. Technol. 2009, 68, 178-184. [CrossRef]

30. Chen, C.-H.; Ma, Y.H. The effect of $\mathrm{H}_{2} \mathrm{~S}$ on the performance of $\mathrm{Pd}$ and $\mathrm{Pd} / \mathrm{Au}$ composite membrane. J. Membr. Sci. 2010, 362, 535-544. [CrossRef]

31. Caravella, A.; Scura, F.; barbieri, G.; Drioli, E. Inhibition by CO and Polarization in Pd-Based Membranes: A Novel Permeation Reduction Coefficient. J. Phys. Chem. B 2010, 114, 12264-12276. [CrossRef]

32. Miguel, C.; Mendes, A.; Tosti, S.; Madeira, L.M. Effect of $\mathrm{CO}$ and $\mathrm{CO}_{2}$ on $\mathrm{H}_{2}$ permeation through finger-like Pd-Ag membranes. Int. J. Hydrog. Energy 2012, 37, 12680-12687. [CrossRef]

33. Kurokawa, H.; Yakabe, H.; Yasuda, I.; Peters, T.; Bredesen, R. Inhibition effect of CO on hydrogen permeability of Pd-Ag membrane applied in a microchannel module configuration. Int. J. Hydrog. Energy 2014, 39, 17201-17209. [CrossRef]

34. Kulprathipanja, A.; Alptekin, G.; Falconer, J.; Way, J. Pd and Pd-Cu membranes: Inhibition of H permeation by HS. J. Membr. Sci. 2005, 254, 49-62. [CrossRef]

35. Gao, H.; Lin, Y.; Li, Y.; Zhang, B. Chemical Stability and Its Improvement of Palladium-Based Metallic Membranes. Ind. Eng. Chem. Res. 2004, 43, 6920-6930. [CrossRef] 
36. Fernandez, E.E.; Helmi, A.; Coenen, K.K.; Rey, J.M.; Viviente, J.L.; Tanaka, D.A.P.; Annaland, M.M.V.S.; Gallucci, F.F. Development of thin Pd-Ag supported membranes for fluidized bed membrane reactors including WGS related gases. Int. J. Hydrog. Energy 2015, 40, 3506-3519. [CrossRef]

37. De Nooijer, N.; Sanchez, J.D.; Melendez, J.; Fernandez, E.; Tanaka, D.A.P.; Annaland, M.V.S.; Gallucci, F. Influence of $\mathrm{H}_{2} \mathrm{~S}$ on the hydrogen flux of thin-film PdAgAu membranes. Int. J. Hydrog. Energy 2020, 45, 7303-7312. [CrossRef]

38. Montesinos, H.; Julián, I.; Herguido, J.; Menéndez, M. Effect of the presence of light hydrocarbon mixtures on hydrogen permeance through Pd-Ag alloyed membranes. Int. J. Hydrog. Energy 2015, 40, 3462-3471. [CrossRef]

39. Peters, T.; Liron, O.; Tschentscher, R.; Sheintuch, M.; Bredesen, R. Investigation of Pd-based membranes in propane dehydrogenation (PDH) processes. Chem. Eng. J. 2016, 305, 191-200. [CrossRef]

40. Easa, J.; Jin, R.; O’Brien, C.P. Evolution of surface and bulk carbon species derived from propylene and their influence on the interaction of hydrogen with palladium. J. Membr. Sci. 2020, 596, 117738. [CrossRef]

41. Palo, E.; Iaquaniello, G. Method for olefins production. U.S. Patent 9776935B2, 28 March 2012.

42. Boeltken, T.; Belimov, M.; Pfeifer, P.; Peters, T.; Bredesen, R.; Dittmeyer, R. Fabrication and testing of a planar microstructured concept module with integrated palladium membranes. Chem. Eng. Process. Process. Intensif. 2013, 67, 136-147. [CrossRef]

43. Mejdell, A.; Peters, T.; Stange, M.; Venvik, H.; Bredesen, R. Performance and application of thin Pd-alloy hydrogen separation membranes in different configurations. J. Taiwan Inst. Chem. Eng. 2009, 40, 253-259. [CrossRef]

44. Peters, T.; Polfus, J.M.; Van Berkel, F.; Bredesen, R. Interplay between propylene and $\mathrm{H}_{2} \mathrm{~S}$ co-adsorption on the $\mathrm{H}_{2}$ flux characteristics of Pd-alloy membranes employed in propane dehydrogenation (PDH) processes. Chem. Eng. J. 2016, 304, 134-140. [CrossRef]

45. Peters, T.; Stange, M.; Veenstra, P.; Nijmeijer, A.; Bredesen, R. The performance of Pd-Ag alloy membrane films under exposure to trace amounts of $\mathrm{H}_{2}$ S. J. Membr. Sci. 2016, 499, 105-115. [CrossRef]

46. Peters, T.; Polfus, J.M.; Stange, M.; Veenstra, P.; Nijmeijer, A.; Bredesen, R. H 2 flux inhibition and stability of Pd-Ag membranes under exposure to trace amounts of NH 3. Fuel Process. Technol. 2016, 152, 259-265. [CrossRef]

47. Tucho, W.M.; Venvik, H.; Stange, M.; Walmsley, J.C.; Holmestad, R.; Bredesen, R. Effects of thermal activation on hydrogen permeation properties of thin, self-supported Pd/Ag membranes. Sep. Purif. Technol. 2009, 68, 403-410. [CrossRef]

48. Mejdell, A.; Klette,H.; Ramachandran, A.; Borg, A.L.; Bredesen, R. Hydrogen permeation of thin, free-standing Pd/Ag23\% membranes before and after heat treatment in air. J. Membr. Sci. 2008, 307, 96-104. [CrossRef]

49. Reyerson, L.H.; Cines, M.R. Adsorption of Propane and Propylene by Silica Gel and Metallized Silica Gel. J. Phys. Chem. 1942, 46, 1060-1068. [CrossRef]

50. Abir, H.; Sheintuch, M. Modeling $\mathrm{H}_{2}$ transport through a Pd or Pd/Ag membrane, and its inhibition by co-adsorbates, from first principles. J. Membr. Sci. 2014, 466, 58-69. [CrossRef]

51. Roa, F.; Way, J. The effect of air exposure on palladium-copper composite membranes. Appl. Surf. Sci. 2005, 240, 85-104. [CrossRef]

52. Tsai, C.Y.; Tam, S.Y. Hydrogen selective protective coating, coated article and method. U.S. Patent 13/581,587, 21 March 2011.

53. Yu, J.; Qi, C.; Zhang, J.; Bao, C.; Xu, H. Synthesis of a zeolite membrane as a protective layer on a metallic Pd composite membrane for hydrogen purification. J. Mater. Chem. A 2015, 3, 5000-5006. [CrossRef]

54. Akporiaye, D.; Jensen, S.F.; Olsbye, U.; Rohr, F.; Rytter, E.; Rønnekleiv, A.M.; Spjelkavik, A.I. A Novel, Highly Efficient Catalyst for Propane Dehydrogenation. Ind. Eng. Chem. Res. 2001, 40, 4741-4748. [CrossRef]

55. Peters, T.; Stange, M.; Sunding, M.; Bredesen, R. Stability investigation of micro-configured Pd-Ag membrane modules - Effect of operating temperature and pressure. Int. J. Hydrog. Energy 2015, 40, 3497-3505. [CrossRef]

56. Peters, T.; Tucho, W.M.; Ramachandran, A.; Stange, M.; Walmsley, J.C.; Holmestad, R.; Borg, A.L.; Bredesen, R. Thin Pd-23\%Ag/stainless steel composite membranes: Long-term stability, life-time estimation and post-process characterisation. J. Membr. Sci. 2009, 326, 572-581. [CrossRef]

57. Mardilovich, P.P.; She, Y.; Ma, Y.H.; Rei, M.-H. Defect-free palladium membranes on porous stainless-steel support. AIChE J. 1998, 44, 310-322. [CrossRef] 
58. Peters, T.; Carvalho, P.; Van Wees, J.; Overbeek, J.; Sagvolden, E.; Van Berkel, F.; Løvvik, O.M.; Bredesen, R. Leakage evolution and atomic-scale changes in Pd-based membranes induced by long-term hydrogen permeation. J. Membr. Sci. 2018, 563, 398-404. [CrossRef]

59. Peters, T.; Carvalho, P.; Stange, M.; Bredesen, R. Formation of hydrogen bubbles in Pd-Ag membranes during $\mathrm{H}_{2}$ permeation. Int. J. Hydrog. Energy 2020, 45, 7488-7496. [CrossRef]

60. Polfus, J.M.; Løwik, O.M.; Bredesen, R.; Peters, T. Hydrogen Induced Vacancy Clustering and Void Formation Mechanisms at Grain Boundaries in Palladium. Acta Mater. 2020. In press.

61. Guazzone, F.; Engwall, E.E.; Ma, Y.H. Effects of surface activity, defects and mass transfer on hydrogen permeance and n-value in composite palladium-porous stainless steel membranes. Catal. Today 2006, 118, 24-31. [CrossRef]

62. Tucho, W.M.; Venvik, H.J.; Walmsley, J.C.; Stange, M.; Ramachandran, A.; Mathiesen, R.H.; Borg, A.; Bredesen, R. and Holmesstad, R. Microstructural studies of self-supported $(1.5-10 \mu \mathrm{m}) \mathrm{Pd} / 23 \mathrm{wt} \% \mathrm{Ag}$ hydrogen separation membranes subjected to different heat treatments. J. Mater. Sci. 2009, 44, 4429-4442. [CrossRef]

Publisher's Note: MDPI stays neutral with regard to jurisdictional claims in published maps and institutional affiliations.

(C) 2020 by the authors. Licensee MDPI, Basel, Switzerland. This article is an open access article distributed under the terms and conditions of the Creative Commons Attribution (CC BY) license (http://creativecommons.org/licenses/by/4.0/). 